\title{
Statistical analysis of helminthic infection in house mouse (Mus musculus) district Nausharo Feroz, Sindh, Pakistan
}

\author{
Maree Rajper*, Nadir Ali Birmani, Saima Naz and Muhammad \\ Moosa Abro \\ Department of Zoology, University of Sindh, Jamshoro, Sindh-Pakistan \\ *Corresponding author's email: rajparmarvi@gmail.com \\ Citation \\ Maree Rajper, Nadir Ali Birmani, Saima Naz and Muhammad Moosa Abro. Statistical analysis of helminthic \\ infection in house mouse (Mus musculus) district Nausharo Feroz, Sindh, Pakistan. Pure and Applied Biology. \\ Vol. 7, Issue 1, pp356-364. http://dx.doi.org/10.19045/bspab.2018.70044
}

\begin{tabular}{llll}
\hline \hline Received: 17/10/2017 & Revised: 26/02/2018 & Accepted: 27/02/2018 & Online First: 07/03/2018 \\
\hline \hline
\end{tabular}

\section{Abstract}

The house mouse (Mus musculus) act as definite host as well as intermediate to spread parasitic disease in human and animals. Studies on helminths infection in house mouse are rare in Pakistan and Sindh their not any significant studies on helminths of the house mouse (Mus musculus). The main aim of this study to describe helminth infection the first time which was recorded during this study. A total of 32 house mouse (Mus musculus) were collected from residential areas of district Nausharo Feroz and dissected for the presence of helminthic infection. Results revealed $62.25 \%$ of helminth infection in the mice collected. Among helminths, the highest prevalence $(72.2 \%)$ was found for the nematodes, followed by the cestodes $(15.2 \%)$. The minimum prevalence was found for the trematode (12.5\%). Amongst helminths, only five species have been identified including two species of nematodes, two species of trematodes and only one species of cestode. In Nematode species the highest prevalence was found for Syphacia muris Yamaguti, 1935 (9.61\%) and minimum ware found for Aspiculuris tetraptera (5.7\%) these both parasite are previously reported worldwide. In Pakistan Syphacia muris Yamaguti, 1935 previously reported but Aspiculuris tetraptera (Nitzsch, 1821) Schulz, 1924 having a new record. In cestode, the larval stage of Taenia taeniaeformis (Batsch, 1786) was found (54.5\%) previously reported from Pakistan. In trematode, the highest prevalence was found for Artyfinostomum indicum (Bhalerao, 1931) Mendheim, 1943 (88.8\%) and minimum found in Artyfinostomum sufrartyfex Lane, 1915 (11.11\%). These both species are first time reported from Pakistan and A. indicum (Bhalerao, 1931) Mendheim, 1943 having new host record also.

Keywords: Helminthic infection; New record; Prevalence

\section{Introduction}

The house mouse (Mus musculus) is one of the most widely distributed and successful mammals in the world [1] In Pakistan, about 174 mammal species living, and mammalian order 18 were present [2] In Pakistan, there are variety of habitats for living of Mice, these include forests, agricultural areas, most populated areas like cities, towns and villages but House mouse is found in human associated habitats like houses and cultivated fields [3] Sindh has a different type of habitats like a coastal area of Karachi to greenery of interior Sindh and 
dry area of Thar Desert so Sindh is rich habitat for Rodentia order and especially Muridae found 7 in number, followed by Sciuridae, Hystricidae and Soricidae has been found 1 for each [4]

House mouse (Mus musculus) is a wellknown major economic pest, contaminating food items and grains [5] Rodents carry many zoonotic diseases, they were responsible for vector-borne diseases. Rodents are responsible for transferring 60 known diseases to human and number is growing [6] due to their breed and they occupying the high range of man-made habitats [7]This disease or infection to transfer to the human body through contaminated food with urine and dropping and bite of ectoparasite like lice, mites and mosquito bite [8]

Rats and House mouse (Mus musculus) is also responsible to transfer protozonal, nematodal and cestodal infection to the human. Rats and House mouse (Mus musculus) are living with a human in same habitats, so they transmitted the infection to human [9, 10] In South-Asia, the nematodes cause most serious disease, in young children. In human, the nematodal infection caused by species Angiostrongylus cantonensis causes significant damage to the brain and spinal cord of human. In cestode, $H$. diminuta is a parasite of House mouse (Mus musculus) and Rats are their definite host and present in worldwide. But the cestodal infection is caused by a human through accidental ingestion of secondary host arthropod [11, 12]. The trematodiasis caused by trematodes by using contaminated food or water. These trematodes infect host's lungs, liver and intestine. These trematodes are found in South East Asia, including India and Pakistan. Trematodiases infect 56 million people all over the world according to WHO in the time period of 1980-2005 [13] WHO experts keep eye on rodentborne diseases, so more than 20 million people were victimized by infection caused by rodents [14] It was decided to find the incidence of helminths in Pakistan as well
Sindh province in house mouse (Mus musculus) and as a result, the present report dealing with the first record of host, locality record and prevalence of selected area. And the present study which provides some useful information on the helminths parasite of the house mouse(Mus musculus) and distribution patterns in talukas of district Nausharo Feroz; distinguish infection in cities and villages of Nausharo Feroz, Sindh, Pakistan. The knowledge will generate awareness to overcome overloaded population of Rats and Mice in Pakistan and find out helminths parasite of House mouse (Mus musculus).

\section{Materials and methods Trapping of live specimens}

Live House Mouse (Mus musculus) were collected from five talukas of Nausharo Feroz. These included 1) Bhiria 2) Kandioro 3) Mehrabpur 4) Moro and 5) Nausharo Feroz. These locations were selected on the basis of the social and economic status of the people. City areas are mostly business-oriented segments of society and village are most congested areas with poorly developed in facilities in this district. Among well -developed city areas like residential and adjacent area (railways, road), shops, flour mills and departmental stores. Less developed areas villages like, Mud houses, Godams and different mills (flour, rice). These sites were randomly selected for collection of House Mice.

Several cages were collected on a weekly basis during one year of the study period and a total number of 32 mice were sampled during one year study period. The cages were set at dusk and collected sample at next dawn. The captured specimens were tagged with locality and date of collection.

Examination of gut contents and visceral organs

After killing, the hosts were placed on dissecting tray. Hosts were cut longitudinally to remove all internal organs. The gastrointestinal tract which divided into four parts including oesophagus, stomach, small intestine and caecum. Other 
organs including lungs, liver, kidneys etcetera were also removed and placed in Petri plates separately. Some saline solution was added to Petri dishes containing these organs. Stomach was cut from surface layer with the help of fine scissors and forceps. The normal saline solution was used to separate parasites from walls and contents of the stomach. Complete gastro intestinal tract was opened length wise from the anterior part of the small intestine in a Petri dish containing a saline solution. The Liver was punctured with the help of fine needles. Care was taken to damage any parasite or cyst inside the liver. Lungs were also punctured with fine needles to open helminth worms within.

Helminths were collected from different organs with the help of needles, forceps and fine brushes. Care was taken to save scolex of cestodes because they are frequently attached to a small intestinal wall then leave in the solution for few minute. Helminths were rancid in normal saline solution and then distilled water two to three times to shed off excess mucous attached to them. The Magnifying glass was also used to collect helminths with the naked eye. Liver of the mice was found to harbour cysts of cestodes. Special care was taken to collect these cysts without causing any damage. After collection of the cyst from the live, these cysts were cut and pressed with a fine brush to collect metacestode.

\section{Statistical analysis}

Prevalence of Infected House mouse, different groups, and helminths species was calculated in percentage $(\%)$ and tabulated in number table 1 and 2 and graphically represented in figure 1 and 2. Chi-square test is used in talukas of district Nausharo Feroz include cities and villages of district Nausharo Feroz for comparison of parameters and tabulated. Then prevalence calculated statistically by chi-square test by using SPSS software version 20 in table 3 and 4 also graphically represented in figure 3 and 4 .

Table 1. Overall prevalence (\%) of House mouse (Mus musculus)* in different groups of helminths

\begin{tabular}{|c|c|c|}
\hline Parasites & Total No.72 & Percentage $\%$ \\
\hline Nematodes & 52 & 72.2 \\
\hline Cestodes & 11 & 15.2 \\
\hline Trematodes & 9 & 12.5 \\
\hline
\end{tabular}

*32 hosts were examined

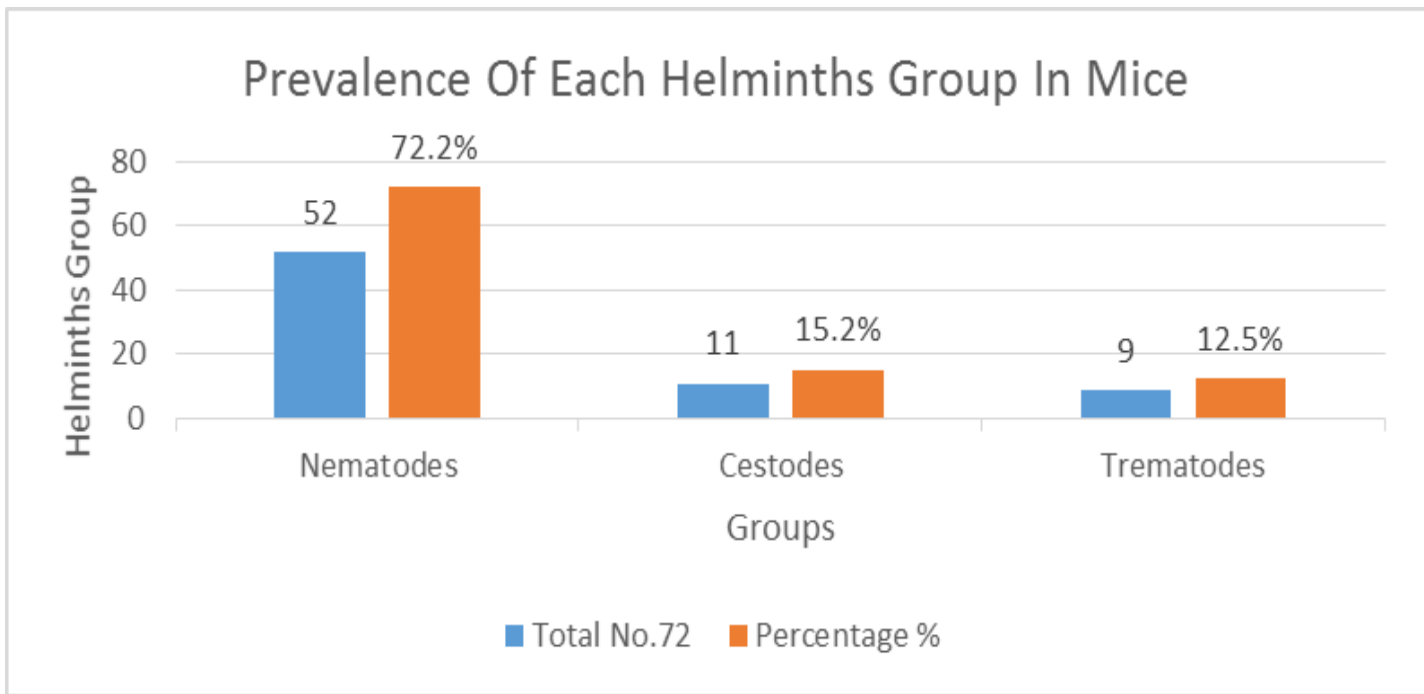

Figure 1. Overall prevalence (\%) of House mouse (Mus musculus) in different groups of helminths 
Table 2. Overall prevalence (\%) of helminths species in House mouse (Mus musculus)* of district Nausharo Feroz, Sindh, Pakistan

\begin{tabular}{|c|c|}
\hline Name of species & Prevalence \\
\hline Nematodes & 9.61 \\
\hline Syphacia muris Yamaguti, 1935 & 5.7 \\
\hline Aspiculuris tetraptera (Nitzsch, 1821) Schulz, 1924 & 54.5 \\
\hline Cestodes & \\
\hline Taenia taeniaeformis (Cysticercus fasciolaris) (Batsch, 1786) & 88.88 \\
\hline Artyfinostomum indicum (Bhalerao, 1931) Mendheim, 1943 & 11.11 \\
\hline Artyfinostomum sufrartyfex Lane, 1915 & \\
\hline
\end{tabular}

*32 hosts were examined

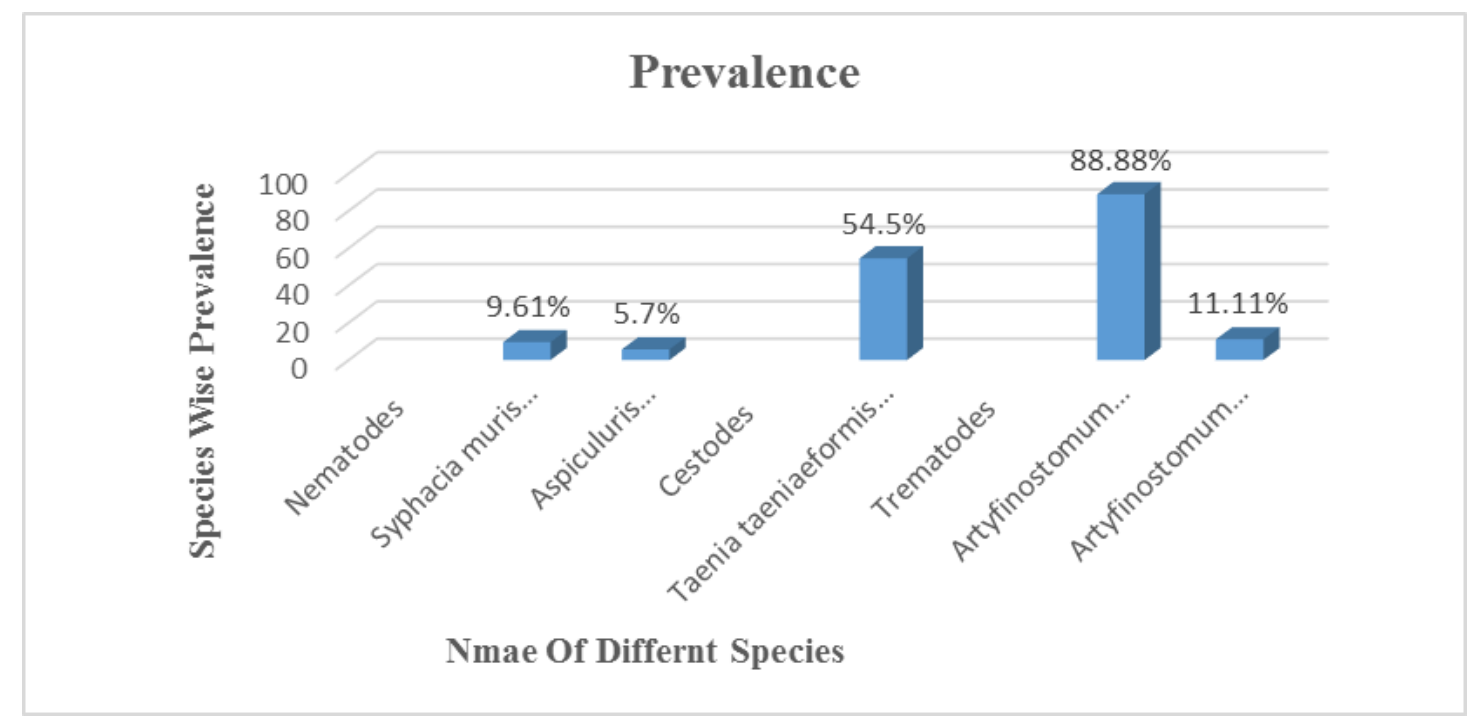

Figure 2. Overall prevalence (\%) of helminths species in House mouse (Mus musculus) of district Nausharo Feroz, Sindh, Pakistan

\section{Results}

During the current study, a total no of 32 house mouse (Mus musculus) was dissected for the presence of helminthic infection. Results revealed $62.2 \%$ of helminth infection in the mice collected. Among helminths, highest prevalence $(72.2 \%)$ was found for the nematodes, followed by the cestodes (15.2\%). The minimum prevalence was found for the trematodes $(12.5 \%)$ given in table 1 and graphically represented in figure 1 .

\section{Areas wise}

House mouse collected talukas of district Nausharo Feroz, among talukas the highest infected mice were found in Moro (50\%), followed by $(42.8 \%)$ in Bhiria, third high infection in the house mouse (Mus musculus) was in Kandioro (40\%), followed by forth high $(33.3 \%)$ in Mahrabpur and minimum prevalence was found in Nausharo Feroz (30.7\%). Chisquare (x2) test showed the prevalence of areas, $(x 2=639$, Degrees of freedom $(\mathrm{df})=4$, probability $(\mathrm{P})=959)$. In district Nausharo Feroz, the developed area like cities there was a less infected mouse, the prevalence was seen $(46.1 \%)$ and the high prevalence was $(63.1 \%)$ in a village of district Nausharo Feroz. Chi-square test used to calculate the prevalence of cities and 
village. Ch-square $x 2=907$, Degrees of freedom $(\mathrm{df})=1$ and probability $(\mathrm{P})=.341$ showed in table 3 and 4 respectively and its prevalence showed graphically in figure 3 and 4.

During the current study House mouse, five helminths were identified with key books. From helminths, two Nematode and one cestode and two trematodes were found. In Nematode the species Syphacia muris was found high prevalence followed by $(9.61 \%)$ and less was Aspiculuris tetraptera (5.7\%). House mouse is an intermediate host of helminths parasite. In cestode Taenia taeniaeformis a liver cyst was frequently found. The prevalence was found in a high number $(54.5 \%)$. In trematodes, the maximum prevalence was found in Artyfinostomum indicum (88.8\%), Artyfinostomum sufrartyfex was found $(11.11 \%)$ minimum in trematodes given in table 2 also graphically represented in figure 2 .

The rat pinworms of the genus Syphacia muris seem to have rather strict hostspecificity and are believed to have the coevolutionary relationship with their hosts, though some host switching could be also possible [15] However, this has been reported previously from Layalpur Pakistan and Srilanka by Baylis 1938. But first -time report from Sindh province.

The nematode group parasitized mice, the family oxyuroid genus Aspiculuris was reported from different part of world Europe, Siberia, China, Japan, India, Pakistan, U.S.A and Argentina. In Pakistan Akhtar [16] distinguish this genus with variation in a body. This genus previously records from Lahore, Pakistan. Secord time reported from Pakistan but first time reported from Sindh. But Aspiculuris tetraptera species reported the first time from Pakistan and Sindh.

This metacestode in literature has also been referred to various names such as bladder worm, Hydatigera fasciolaris, Strobilocercus fasciolaris and Taenia crassicolis [17-19] The definitive host i.e. cat and other felines get infected by the consumption of infected intermediate host's liver [20] Previously this species Taenia taeniaeformis (Cysticercus fasciolaris) have been reported from America, Europe, Africa, Middle East, India and Pakistan. Previously this species is reported by [21] from Lahore, Pakistan. This species is being reported for the second time from Pakistan and first time from Sindh province.

Previously these trematode species Artyfinostomum indicum has been reported by Bhalerao, 1927, Baschkirora, 1947 and Bhardwaj, 1963 as Testisacculus, Reptiliotrema and Pseudoartyfechinostomum respectively from duodenum of Uromastrtric (agamid lizard) in India). Later on, Jain 1910, transferred this species to genus Artyfeshinosomum. Presently this species is reported from the intestine of a mouse (Mus musculus) for the first time from Pakistan, making a new host and locality record. And Artyfinostomum sufrartyfex previously this species is reported from a girl (Human) in Assam, India; also in rats, pigs, cat, and dogs [22] This species is also distributed in Malaysia, Thailand, Indonesia and Philippines. Previously there is no record of this zoonotic species in Pakistan. Therefore, this makes it a new record.

\section{Discussion}

House mouse (Mus musculus) lived in human environments, in the building, house, railways, shops, factories and in villages these occupying mud house and goddam, so has great chances to transfer ecto and endoparasitic disease to human. House mouse (Mus musculus) is also an intermediate host for helminths parasite, so it is important to know its infection of helminths, its intermediate parasite transfer infection in environments. In worldwide their great work seen on helminth parasite different locations were Brazil, Nigeria, Argentina, U.S.A, Italy, Egypt and Mexico has been studied previously. The most common pinworm species were Syphacia obvelata, Aspiculuris tetraptera and Syphacia muris. These species distribute 
worldwide [23] Aspiculuris huascaensis a new species has been reported from the mouse in Mexico [24] Trichinella spiralis reported from Faisalabad, Pakistan [25] In Pakistan, Lahore, the scientist genus Aspiculuris with different in the bodies so numerous species like $A$. Americana, Paraspiculuris, A. tetraptera, A. dinniki, A. kazakstanica, A. schulzi and A. lahorica .A. pakistanica had been reported [16] In cestode tapeworm genus Hymenolepis is reported in higher prevalence in a Rat, House mouse (Mus musculus) and occasionally in the hamster. $H$. diminuta has been found in Rats and House mouse (Mus musculus) but requires an intermediate host for complete its developmental stages, these are beetles, fleas and grain-eating arthropods as their intermediate host. In the Rat and Mice live, the white creamy cyst is present for the larval stage of Taenia taeniaformis found named as Cysticercus fascialaris, the larval stage in House mouse (Mus musculus). The House mouse is an intermediate host and if it is eaten by a cat, the definite host of tapeworm developed and caused infection in the cat [26] In cestode the genus Hymenolepis is present in rodents and human distributed southern Asia, another genus Raitlletina has been reported in rodents, these rodents are this primary host. [27].

In Asia, work has been done on helminths of rats and House mouse (Mus musculus) of Indonesia, Iran, Bangladesh, India and Pakistan. Trematodes species were reported

Table 3. Overall prevalence (\%) of House mouse (Mus musculus)* in different talukas of district Nausharo Feroz Sindh, Pakistan

\begin{tabular}{|c|c|c|}
\hline Talukas & No. of mice collected & $\begin{array}{c}\text { Infected mice and its } \\
\text { prevalence (\%) }\end{array}$ \\
\hline Bhiria & 7 & $3(42.8)$ \\
\hline Kandioro & 5 & $2(40)$ \\
\hline Mehrabpur & 3 & $1(33.3)$ \\
\hline Moro & 4 & $2(50)$ \\
\hline Naushahro Feroz & 13 & $4(30.7)$ \\
\hline Total & 32 & $20(62.25)$ \\
\hline
\end{tabular}

*32 hosts were examined from India from various infected hosts. Artyfechinostomum surfrartyfex Lane, 1915 previously this species is reported from a girl (Human) in Assam, India; also in rats, pigs, cat, and dogs (Matta and Pande, 1966; Rai and Ahluwalia, 1958 and Mohandas, 1971) respectively. This species is also distributed in Malaysia, Thailand, Indonesia and Philippines. Another trematode species Echinostoma malayanum recorded by Leiper (1911) from a man in Malaya found to infect pigs and house-shrews. This species also found in infected in white rats, white mice, and hamsters byLie Kian Joe, 1963. Artyfechinostomum mehrai Jain, 1960, Artyfechinostomum indicum (Bhalerao, 1931) Mendheim, 1943, Artyfechinostomum paradoxuri Baugh, 1962, Artyfechinostomum varanum Simha and Deshpande, 1964, Artyfechinostomum munshii Deodhar et al., 1967, Neoartyfechinostomum Agarwal, 1963, N. shubhrai Agarwal, 1963 from India infected various mammalian hosts [22] In trematodes genus Paragonimus is found in the various mammalian hosts as well as rodents and human from South-East Asia, and Pacific region [27] Therefore, the detailed study of helminths group studied as mentioned in record and prevalence .In helminths group, most of the parasites were first time studied from Pakistan, mostly Punjab province. But in Sindh helminths parasite of House mouse (Mus musculus) first time studied. 


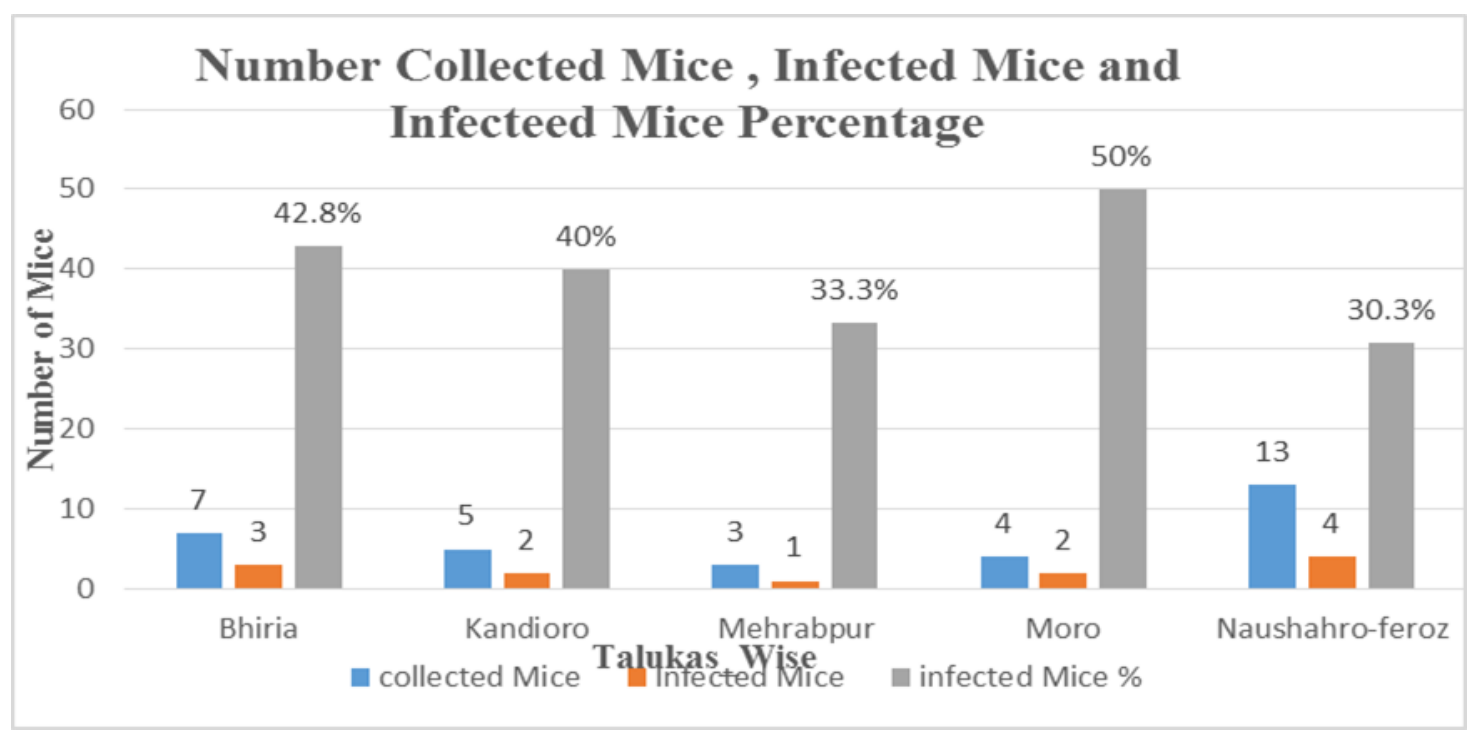

Figure 3. Shows the number of collected mice, infected mice and infected mice percentage in different talukas of district Nausharo Feroz Sindh, Pakistan

Table 4. Overall prevalence (\%) of House mouse (Mus musculus)* in city and village of the district Nausharo Feroz, Sindh, Pakistan

\begin{tabular}{|l|l|l|}
\hline Area & No of mice collected & $\begin{array}{l}\text { Infected mice and its } \\
\text { Prevalence (\%) }\end{array}$ \\
\hline City & 13 & $6(46.1)$ \\
\hline Village & 19 & $12(63.1)$ \\
\hline
\end{tabular}

*32 hosts were examined

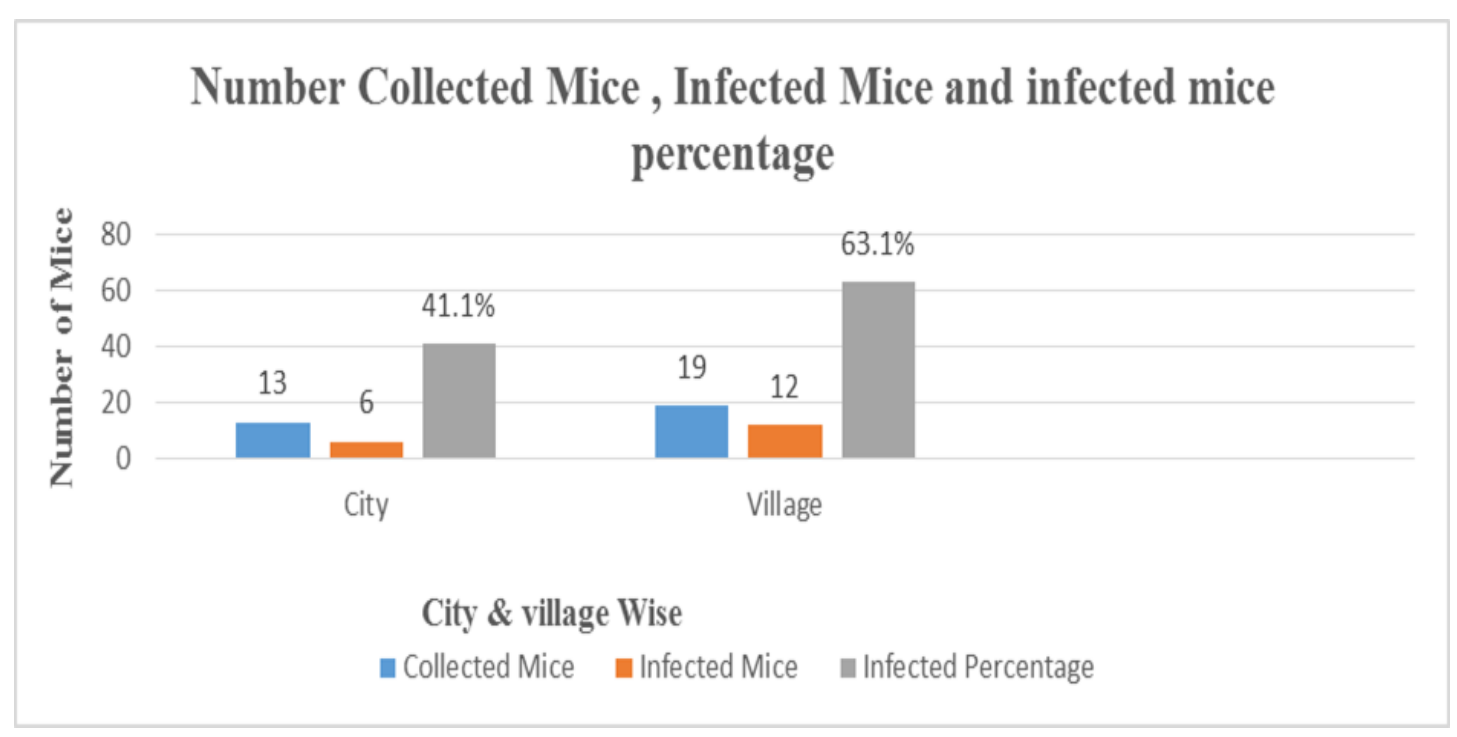

Figure 4. Show the number of collected mice, infected mice and infected mice percentage in city and village of the district Nausharo Feroz, Sindh, Pakistan

\section{Conclusion}

It concludes that helminth parasite of (Mus musculus) first time studied in the district Nausharo Feroz, Sindh, Pakistan. This study Statistical analysis of helminthic infection and present in area and groups of helminths also a new record in Pakistan and Sindh Province Present paper will be 
helpful in further study on the present host, parasite and locality.

\section{Authors' contributions}

Conceived and designed the experiments: M Rajper \& NA Birmani, Performed the experiments: M Rajper, Analyzed the data: M Rajper, S Naz \& MM Abro, Contributed materials/ analysis/ tools: NA Birmani \& S Naz, Wrote the paper: M Rajper, NA Birmani, S Naz \& MM Abro.

\section{Acknowledgement}

To the research associate, Majid Hussain, Department of Information technology Shaheed Benazir Bhutto, Naushahro-Feroz campus and providing the SPSS software, suggestions and help in the chi-square test.

\section{Reference}

1. Mammals Trust UK. (2003). http://www.mtuk.org/index.p hp?page $=$ mammal_rodents.

2. Roberts TJ (1997). The Mammals of Pakistan. 2nd Ed. Oxford University Press, Oxford, UK.

3. Ballenger L (1999). "Mus musculus" (On-line), Animal Diversity Web. Accessed November 12, 2015 at http://animaldiversity.org/accounts/M us_musculus/

4. Begum A, Khan MZ, Khan AR, Zehra A, Hussain B, Siddiqui S \& Tabbassum F ( 2013). Current status of Mammals and Reptiles at Hub dam Area, Sindh / Balochistan, Pakistan. Processing in Curr World Environ 8(3): 395-402.

5. Corbet GB \& Southern HN (1977). The handbook of British mammals. Second Edition. Blackwell Scientific Publications, London.

6. Khatoon N, Bilqees FM, Shahwar D \& Rizwana AG (2004). Histopathological alterations associated with Syhacia spp. (Nematode) in the intestine of moles in Bangladesh. Pak Vet J 5: 143144.

7. Parshad VR (1999). Rodent control in India. Integrated Pest Management Reviews 4(2): 97-126.

8. Ruiz A (2004). Rodents in disasters. Article for Vaccination Program. Pan American Health Org USA pp: 18.
9. Webster JP \& Macdonald DW (1995). Cryptosporidiosis reservoir in wild brown rats (Rattus norvegicus) in the UK. Epidemiology \& Infection 115(1): 207-209.

10. Channon D, Channon E, Roberts T \& Haines R (2006). Hotspots: are some areas of sewer network prone to reinfestation by rats (Rattus norvegicus) year after year. Epidemiology \& Infection 134(1): 41-48.

11. Acha PN \& Szyfres B (2003). Zoonosis y enfermedades transmisibles comunes al hombre ya los animales: Volumen I. Organización Panamericana de la Salud.

12. Baily GC (1996). Intestinal cestodes, p. 1477-1485. In GC Cook (ed.), Manson's Tropical Diseases, 10th ed. WB Saunders Company, Ltd., London, England.

13. Tandon V, Shylla JA, Ghatani S, Athokpam VD \& Sahu R (2015). Neglected Tropical Diseases: Trematodiases-The Indian Scenario. Proceedings of the National Academy of Sciences, India Section B: Biological Sciences 85(4): 901-907.

14. World Health Organization (2007). Report of the fifth consultative meeting on leishmania/HIV coinfection. Addis Ababa, Ethiopia 20-22.

15. Hugot JP (1988). Les Nématodes Syphaciinae parasites de Rongeurs et de Lagomorphes. Taxonomie, Zoogeographie, Evolution. Bull Mus Natl Hist Nat Série A 141:1-153.

16. Akhtar SA (1955). On nematode parasites of rats and mice of Lahore, with some remarks on the genus Aspiculuris Schulz, 1924 and two news species of the genus. Pakistan $J$ of Scientific Research 7: 104-111.

17. Mc Coy Gw (1909). A preliminary report of tumors found in wild rats. $J$ Med Res 21: 283.

18. Hsu CK (1979). The laboratory rat. In: Baker HG, Lindsey JR, Weisbroth SH (eds) Biology and disease. Academic Press, New York, pp 314-315. 
19. Kass PH, Barnes Jr WG, Spangler WL, Chomel BB \& Culbertson MR (1993). Epidemiologic evidence for a causal relation between vaccination and fibrosarcoma tumorigenesis in cats. $J$ of the American Veterinary Medical Association 203(3): 396-405.

20. Singla LD, Aulakh GS, Sharma R, Juyal PD \& Singh J (2009). Concurrent infection of Taenia taeniaeformis and Isospora felis in a stray kitten: a case report. Vet Med 54(2): 81-83.

21. Ahmed MS (2009).Studies on rats and mice as a reservoir of zoonotic parasites proceeding of parasitology university of veterinary and animals science, Lahore Thesis pp 57-69.

22. Premvati G \& Pande Vibha (1974). On Artifechinostomum malayanum (Leiper, 1911) Mendheim, 1943 (Trematoda: Echinostomatidae) with synonymy of allied species and genera. Proceed Helminthol Soc Washington 41(41): 151-160.

23. Perec-Matysiak A, Okulewicz A, Hildebrand J \& Zaleśny G (2006).
Helminth parasites of laboratory mice and rats. Wiadomosci Parazytologiczne 52(2): 99-102.

24. Falcón-Ordaz J, Pulido-Flores G \& Monks S (2010). New species of Aspiculuris (Nematoda: Heteroxynematidae), parasite of $M u s$ musculus (Rodentia: Muridae), from Hidalgo, Mexico. Revista Mexicana de Biodiversidad 81(3): 669-676.

25. Rafique A, Rana SA, Khan H A \& Sohail A (2009). Prevalence of some helminths in rodents captured from different city structures including poultry farms and human population of Faisalabad, Pakistan. Pak Vet J 29(3): 141-144.

26. Griffiths HJ (1971). Some common parasites of small laboratory animals. Laboratory Animals 5(1): 123-135.

27. Aplin K P, Brown PR, Jacob J, Krebs C J and Singleton G R (2003). Field methods for rodent studies in Asia and the Indo-Pacific. ACIAR Monograph No. 100: 223p. 